\title{
EFFECT OF FINANCIAL PERFORMANCE AGAINST MARKET PERFORMANCE IN BANKING
}

\author{
Desry Ponisa Putra ${ }^{1)}$, Seto Sulaksono Adi Wibowo ${ }^{2)}$ \\ Managerial Accounting Department, Politeknik Negeri Batam \\ Jl. Ahmad Yani, Batam Centre, Batam 29461, Indonesia \\ 1) E-mail: desry.fournisaputra@gmail.com \\ ${ }^{2)}$ E-mail: seto@polibatam.ac.id
}

\begin{abstract}
This study aims to examine the effect of the financial performance of the banking market performance. This study used a sample of banking companies listed in Indonesia Stock Exchange 2011-2013. Financial Kineja measured using CAMEL (Capital, Asset Quality, Management, Earnings and Liquidity). market-based financial performance is measured by stock returns, variable we used in this study are the independent variables which covers CAR, DER, ROA, LDR. Data research using panel data and methods of data analysis using simple linear regression. influence the financial performance against the performance of the market is not particularly a significant impact on the performance of banks.
\end{abstract}

\section{Keywords: financial performance, market performance, CAR, DER ROA, LDR.}

\section{Introduction}

Banking companies have an important role in the life of society. According Kusumawati (2012) the bank is regarded as driving the economy of a country. The primary function of banks in economic development namely as an institution to collect public funds in the form of deposits, as institutions that channel funds to the community in the form of credit, as the institution that launched the trade and circulation of money. Achieving corporate goals is one of the determining factors in the future to moving towards a better, therefore, most companies choose to increase the company's operational activities although the company must perform additional capital, but this sometimes be limited for most companies. The existence of the stock market is a very important tool in the economy, both for investors as well as alternative sources of funding. Capital market development in Indonesia is very fast it can be seen from the number of companies listed on the Indonesian Stock Exchange (BEI) and the increasing interest of the public to invest in the next 5 years in terms of quantity, of course, investors also prefer companies with good financial performance to invest because the main purpose of investors in investing is to make a good profit with the form of capital (capital gains) or the dividend when investing in stocks (Gumanti, 2011). Measurement of financial performance can be measured by several approaches, two of which can be measured by financial performance-based approach to accounting and financial performance based on the market as measured by stock returns. Measurement of financial performance are necessary to assist investors in assessing the right company to invest because it is basically an investor requires analysis of the performance of the company as a basis for making investment decisions in the hope of obtaining the level of decision (Rate Of Return) which is comparable to the level of risk to be taken investor. Analysis of financial statements that many of the company in measuring the financial performance is on the basis of accounting is to use the conventional method of 
financial ratio analysis. Analysis commonly used in the study is the financial performance measure Return On Asset (ROA), Return on Equity (ROE), which is associated with stock returns. 1993 firm Stern Stewart \& Co. developed the concept of Economic Value Added (EVA) to complete financial ratio analysis (Simbolon et al, 2014). Research on the relationship of financial performance based accounting and market-based financial performance as measured by stock returns in the manufacturing companies have done, while studies on the association of accounting based on the financial performance and financial performance is based on the banking market as measured by stock returns are still very rare. Referring to previous research conducted by Lili (2013) who studied accounting-based performance measurement and performance based on the market, Researchers are interested in developing such research in Indonesia.

\section{Theoritical}

\subsection{Agency Theory}

According to Jensen (2001) agency theory is a concept that describes the contractual relationship between the management (agent) with shareholders (Principal). Both sides have their respective positions are Pricipal as capital owners have access to the company's internal information while the agent is an actor in operational practices and companies with information on the performance and operational rill making it possible conflicts between the two parties. Based on agency theory Prisipal hard to believe that the management (agent) will always act in the interests of shareholders, so it is necessary to control the stock of the owner of the shares.

\subsection{Income Smoothing}

Stakeholder Theory states that the company has a responsibility to the stakeholders for information on how the organization's activities affect them. In this case the company must ensure that the rights of stakeholders must be met to maintain the viability of the company (Freeman, 2010). One form of that responsibility is to improve the company's image is reflected by an increase in the company's increase in stock returns.

\subsection{Profitability}

Companies typically measure financial performance based accounting as a financial indicator that is commonly seen on the company's financial statements. The financial statements usually provide information concerning the financial position, the Company activities, financial health of the company, and the company's performance that are beneficial for the parties concerned to take economic decisions (Sjahrial, 2012).The financial performance of the company, is among the basis of the assessment of the financial condition of companies that is based on an analysis of the company's financial ratios (Munawir, 2010). Financial performance is one of the main factors considered by investors in making investment decisions. The company's financial performance is the result of the company in managing and allocating resources during a certain period and described in the financial statements.

\subsection{Firm Size}

Financial ratio analysis is a measurement of financial performance based accounting is often done. During this analysis used financial ratios divided into four parts, Activity Ratios, Profitability Ratios, Liquidity Ratio, Leverage Ratio (Sartono, 2001). Besides the valuation of the bank in Indonesia to date is based on a factor CAMEL (Capital, Assets Quality Management, Earnings and Liquidity). Along with implementing risk-based supervision, the rating also need improvement. $\mathrm{BI}$ is currently preparing a refinement of the new bank rating system, which takes into account sensitivity to market risk or market risk. Thus factors - factors taken into account by the new system are CAMEL.

\subsection{Financial Leverage}

Financial performance is measured based on the market-based rate of return. According Hoskissonet al (1994) past performance is measured using accounting data is a good predictor of the future performance as measured using market data. They found a significant relationship between accounting-based performance measurement and market-based performance measurement. Market-based financial performance measurement in this study was measured by stock returns. Return 
the results obtained from the investment. Investor menggunakaninformasi accounting or financial performance measurement based accounting to measure stock returns that can be obtained in the future.

\subsection{Hypothesis}

Research in Indonesia more financial ratio analysis with stock returns, as research conducted by Ngaisah (2008) found that ROA and ROE partially significant positive effect on stock returns. The results of different studies by Hasanah (2008) found that ROA positive and significant effect on stock returns and ROE significant negative effect on stock returns. Marini (2008) found that EVA partially positive and significant effect on stock returns in banking companies listed on the Stock Exchange. Wibisono (2010) found EVA and ROE effect on stock returns. Rahayu \& Aisjah (2012) found that EVA does not influence simultaneously on stock returns. Research by Berakon (2012) showed that the EVA has no effect on stock returns in BEI. While Thrisye \& Simu (2013) found that the Return on Assets (ROA) is not positive and significant effect on stock returns .. Based on the above, the proposed hypothesis is $\mathrm{H}$ : Financial performance (Camel) positive effect on market performance (Return Shares).

\section{Results and Discussion}

\section{Population, Sample, and Sampling Techniques}

Population, Sample and Sampling TechniquesThis study uses panel data which is a combination of time series data and cross section. The population in this study were banking companies listed in Indonesia Stock Exchange (BEI) 2011-2013. The selected companies are companies in the banking sector. This study uses secondary data obtained from the Indonesia Stock Exchange (BEI) in 2011-2013. The population of this research are banking companies listed BEI. Samples were selected in this study using purposive sampling method with the following sample criteria; (1) The Company publishes full financial statements in the period 2011 to 2013, (2) Companies that have financial data relating to variable research is complete. Data collection techniques that researchers use the data archive. Researchers will be looking for a study of data from related sources, such as the Indonesia Stock Exchange (IDX), which can be accessed through the website www.idx.co.id, Indonesian Capital Market Directory, and Bank Indonesia.

\section{Hypothesis Test}

Hypothesis testing using a one-way or one-tailed, because the independent variable is expected to have a positive effect on the dependent variable. The testing of hypotheses using software eviews using Least Square (LS). The model of this research is to use quantitative data analysis. To test the hypothesis of financial performance (Camel) positive effect on market performance (Return Shares) used the research model as follows:

Information :

Return Saham $=$ Stock Returns

$\mathrm{CAR}=$ Capital Adequancy Ratio

DER $=$ Dep To Equity Ratio

LDR $=$ Loan To Deposit Rasio

BOPO = Rasio Biaya Operasional Terhadap Pendapatan Operasional

SIZE $=$ Firm Of Size

AGE $=$ Age Of Firm

Result of hypothesis test can be seen in Table 1 .

Table 1

Results and Resume of Hypothesis Test

Table 1. Least Square (LS)

\begin{tabular}{ccclc}
\hline \hline Variabel & $\begin{array}{c}\text { Coeffi } \\
\text { cient }\end{array}$ & $\begin{array}{c}\text { Std. } \\
\text { Error }\end{array}$ & t-Statistic & Prob. \\
\hline \hline C & $\begin{array}{c}0.0648 \\
01\end{array}$ & $\begin{array}{c}0.0725 \\
30\end{array}$ & 0.893437 & 0.3753 \\
Return Saham & $\begin{array}{c}0.286 \\
059\end{array}$ & $\begin{array}{c}0.3215 \\
01\end{array}$ & -0.889761 & 0.3772 \\
Usia perusahaan & -0.030 & 0.0500 & -0.606898 & 0.5462 \\
Ukuran & 384 & 64 & & \\
perusahaan & 0.0004 & 0.0051 & 0.081645 & 0.9352 \\
\hline \hline
\end{tabular}

Source: Data processed by Eviews

Based on the significance value (Prob), the independent variable $\mathrm{X} 1$ has a value of 0.3772 (sig> 0.05). These values indicate that $\mathrm{H}$ unsupported, these results suggest that stock returns do not affect the value of the company.Control variables $\mathrm{X} 2$ has a significant 
value of 0.0340 ( $\mathrm{sig}<0.05)$, with the value of coefficient -0.323964 showing that age negatively affect sales growth. Control variables X3 has a significant value of 0.7432 which indicates that the variable firm size proxied by total assets has no effect on sales growth.

\section{Conclusions}

From the research results contained in hipotesi can be concluded that the hypothesis is not supported because the value of prof greater than the value of alpha at $(0.3772>0.05)$, which means that the market value does not affect the value of companies in the sample (corporate banking), and the level of stocks are on the market do not affect the value of the company. Values banking companies are more affected by the transaction-level customer / client which could enhance shareholder value.

\section{Limitations and Suggestions}

Researchers realized that this study has limitations, namely:

1. The study period is too short which is only 3 years old.

2. In this study, not all CAMELS ratio is used as a variable so that the results of the research has not been perfect.

This study still has many limitations but the researchers hope this study can provide many benefits for education and further researches. First, the theoretical implications, this research is expected to increase the knowledge about the influence of financial performance to the performance of the banking market. Second, this research is expected to be input and knowledge for the company to further enhance the company's financial performance, and the latter is expected to help investors in considering investment decisions.

Suggestions want researchers give to the next researcher who will conduct similar research are:

1. Extending the period of research into a few years in order to obtain a sample for more and better research results statistically.

2. Adding a proxy measurement of financial performance as economic value added, gross profit margin, and others in order to obtain the research results related to the company's performance in the implementation of ERP systems deeper.

3. Adding the industrial sector other than banks, such as trade, mining, agriculture, and so forth.

\section{References}

IDX Indonesia Stock Exchange. (2010). Retrieved Desember 24, 2014, from idx http://www.idx.co.id/id-id/beranda/informasi/bagiinvest or/indeks.aspx

Indo Premier. (2010). Retrieved Desember 24, 2014, from ipotindonesia:

https://www.ipotindonesia.com/ipot_new/education.php?p age=indeks_saham

Berakon, I. (2012). Analisis Pengaruh Economic Value Added, Market Value Added, dan Return On Investment Terhadap Return Saham Pada Perusahaan yang Terdaftar di Jakarta Islamic Index (JII). Yogyakarta.

Freeman, R. E. (2010). Strategic Management: A Stakeholder Approach. Cambridge University Press

Gumanti, T. A. (2011). Manajemen Investasi Konsep, Teori dan Aplikasi. Jember: Mitra Wacana Media.

Hasanah, L. (2008). Analisis Pengaruh Leverage Keuangan dan Rasio Profitabilitas Terhadap Return Saham Pada Perusahaan yang Terdaftar di Jakarta Islamic Index/JII Tahun 2005-2007.

Hoskisson, R. E., Johnson, R. A., \& Moesel, D. D. (1994, Oktober5). Jstor-The Academy of Management Journal. Retrieved Januari 2015, $3, \quad$ from $\quad$ Jstor: http://www.jstor.org/discover/10.2307/256671?sid=21105 $\underline{722985283 \& \text { uid }=4 \& \text { uid }=2}$

Jensen, M. C. (2001). Foundations of Organizational Strategy. Harvard University Press.

Jensen, M., \& Meckling, W. (n.d.). Theory of The Firm, managerial behavior, agency costs, and ownership structure. Journal of Financial Economic, Vol. 3 No.4, pp.305-306.

Li, L. (2013). Market-based vs. Accounting-based Performance of Bank in Asian Emerging Markets. Asian Journal of Business Research.

Marini, L. (2008). Analisis Pengaruh Economic Value Added (EVA), Return On Equity (ROE) dan Arus Kas Operasi Terhadap Return Saham Pada Perusahaan-Perusahaan yang Terdaftar di Jakarta Islamic Index (JII) Periode 2003-2006. 
Munawir, S. (2010). Analisis Laporan Keuangan Edisi Empat.

Yogyakarta: Liberty.

Ngaisah, S. (2008). Pengaruh Rasio Profitabilitas dan Leverage Terhadap Return Saham Pada Perusahaan yang Terdaftar di Jakarta Islamic Index Tahun 2004-2006.

Rahayu, U. T., \& Aisjah, S. (2012). Pengaruh Economic Value Added dan Market Value Added terhadap Return Saham.

Sartono, R. A. (2001). Manajemen Keuangan Teori dan Aplikasi Edisi 4. Yogyakarta: BPFE Yogyakarta.

Simbolon, R. F., Dzulkirom, M., \& Saifi, M. (2014). Analisis EVA (Economic Value Added) Untuk Menilai Kinerja Keuangan Perusahaan (Studi Pada Perusahaan Farmasi Pada Bursa Efek Indonesia Periode 2010-2012). Jurnal Administrasi Bisnis (JAB) Vol. 8 No. 1, 1-8.

Sjahrial, D. (2012). Pengantar Manajemen Keuangan. Jakarta: Mitra Wacana Media.

Thrisye, R. Y., \& Simu, N. (2013). Analisis Pengaruh Rasio Keuangan Terhadap Return Saham BUMN Sektor Pertambangan Periode 2007-2010. Jurnal Ilmiah Akuntansi dan Bisnis Vol.8 No.2, 75-81.

Wibisono, H. (2010). Analisis Pengaruh Economic Value Added (EVA) dan Rasio Profitabilitas Terhadap Return Saham Pada Perusahaan Manufaktur yang Terdaftar Dalam Indeks LQ-45 Selama Periode 2004 - 2007. 